\title{
Neural representation for distance and direction of resource for honeybees
}

\author{
Sangwook Park, DaeEun Kim \\ From Twentieth Annual Computational Neuroscience Meeting: CNS*2011 \\ Stockholm, Sweden. 23-28 July 2011
}

Many insects manage their foraging behaviors or prey detection based on resource information. Their brain system should encode the resource location efficiently. Honeybees remember the nectar source location and communicate with their colleagues using their own dance language [1]. Desert ants demonstrate elegant homing navigation with path integration [2] and they can estimate the homing vector, distance and direction. We presume they may have common neural structure and representation for the resource vector or homing vector. For the resource vector, we can build a neural network consisting of two layers of neurons, which has a polar form representation. Each neuron is one of directionally selective neurons and also includes the information of the distance. For the distance information, the activation in direction-cell neurons has the exponential form of inhibition to the distance neuron as gate neurons, which resembles multiplicative neurons [3]. A population of the neurons efficiently encodes the resource location, that is, the distance and direction of the resource. The resource vector representation can be applied to honeybees or other insects. It is known that two types of dances in honeybees' dance communication, waggle dances and sickle dances, has the information of resource vector. It has been pointed out that waggle dance has several cues, vibration, odor, air flow and tactile information. From the sickle dance, the colleagues on following the dancer bee can continuously records the duration and direction of its temporal path, and accumulate the information, which finally provides the net distance and direction of the resource from the comb. We suggest the mechanism is similar to the path integration system, although the accumulated distance is replaced by the accumulated duration in the preferred direction

Biological Cybernetics, School of Electrical and Electronic Engineering, Yonsei University, Shinchon, Seoul, 120-749, South Korea in the dance translation. The distance to the resource is involved with duration of the waggle run and duration of the return run [4]. In that point, the neural network can represent the resource information well.

\section{Acknowledgments}

This work was supported by the Mid-career Researcher Program through an NRF grant funded by the MEST (No.2010-0000460).

Published: 18 July 2011

\section{References}

1. von Frisch K: The Dance Language and Orientation of Bees. Harvard University Press, Cambridge; 1967.

2. Mueller M, Wehner R: Path integration in desert ants. Cataglyphis fortis Proc. Nati. Acad. Sci. USA 1988, 85:5287-5290.

3. Gabbiani F, Krapp HG, Koch C, Laurent G: Multiplicative computation in a visual neuron sensitive to looming. Nature 2002, 420(6913):320-324.

4. Seeley TD, Mikheyev AS, Pagano GJ: Dancing bees tune both duration and rate of waggle-run production in relation to nectar-source profitability. Journal of Comparative Physiology A 2000, 186:813-819.

doi:10.1186/1471-2202-12-S1-P169

Cite this article as: Park and Kim: Neural representation for distance and direction of resource for honeybees. BMC Neuroscience 2011 12(Suppl 1): P169.

Submit your next manuscript to BioMed Central and take full advantage of:

- Convenient online submission

- Thorough peer review

- No space constraints or color figure charges

- Immediate publication on acceptance

- Inclusion in PubMed, CAS, Scopus and Google Scholar

- Research which is freely available for redistribution
C Biomed Central

(c) 2011 Park and Kim; licensee BioMed Central Ltd. This is an open access article distributed under the terms of the Creative Commons Attribution License (http://creativecommons.org/licenses/by/2.0), which permits unrestricted use, distribution, and reproduction in any medium, provided the original work is properly cited. 